\title{
Pattern of Skin Diseases: Experience from a Rural Community of Bangladesh
}

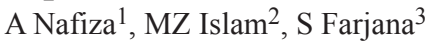

\begin{abstract}
:
Disease pattern in a given population is generally determined by different ecological factors. Thus the objective of this cross-sectional study was to determine the pattern of skin diseases in a selected rural community of Dhamrai Upazila under Dhaka district. Out of 2645 patients attending a medical camp showed 410(15.5\%) patients with dermatological problems. Among all, 260(63.4\%) patients were males and 150(36.6\%) were females with a male to female ratio of 1.7:1. Of these patients, 178(43.4\%) had cutaneous infections and 234(56.6\%) had non-infectious dermatoses. Few patients (2.7\%) had more than one dermatoses. Fungal infection was the commonest infection seen (22.9\%) and eczemas took an upper hand in non-infectious group (32.2\%). Improvement in the standard of living, health education, improvement in the environmental sanitation and good nutritious food may help the people to bring down the skin disease in the rural part of country.
\end{abstract}

Keywords: Rural community, Skin Diseases, Pattern, Risk Factors.

\section{Introduction:}

Disease pattern in a given population is generally determined by different ecological factors. ${ }^{1}$ Dhamrai Upazila is a densely populated area of Dhaka district with high humidity and a heavy rainfall. Due to lack of education, the patients don't report for treatment unless compelled by the severity of the symptoms. ${ }^{2}$ In Bangladesh there is a significant incidence of infectious disorders because of underdeveloped economy and social backwardness. ${ }^{3}$ The selected rural community is also one such place where a high incidence of cutaneous infection was seen.

\section{Materials and methods:}

This Cross-sectional study was conducted during the period of January to June 2008 to determine the pattern of skin diseases in a selected rural community. The rural community $40 \mathrm{Km}$ west to the Dhaka city called "Chandrail (Choto and

1. Dr. Nafiza Ahmed, Assistant Professor, Dermatology, Dhaka Medical College Hospital.

2. Dr. Md. Ziaul Islam, Associate Professor, Department of Community Medicine, National Institute of Preventive and Social Medicine (NIPSOM), Mohakhali, Dhaka.

3. Dr. Sharmin Farjana, Medical Officer, Upazila Health Complex, Nandail, Mymensingh.

\section{Correspondance Author:}

Dr. Md. Ziaul Islam

e-mail: ziauliph67@yahoo.com.
Patients were included in the study irrespective of age and sex considering specific selection criteria. Data was collected by face-to-face interview and clinical examination with the help of a semi-structured questionnaire and checklist respectively. Considering the objectives of the study, a medical camp was organized in a village near to Dhamrai Upazila. All 2645 patients attending the camp were examined under bright sunlight for cutaneous diseases. After diagnosing, they were treated accordingly. All data was processed considering the nature of variables, objectives and maintaining quality control check.

\section{Statistical Analysis:}

Data was analyzed by using the SPSS soft-ware (version-18.0) and accordingly descriptive statistics frequency distribution, percentage and mean \pm SD was estimated. The diseases were classified, tabulated and compared with the similar reports from other parts of the country.

\section{Ethical considerations:}

Informed written/verbal consent was taken form the individual patient prior to inclusion in the study. They were also informed about the objectives, procedure and benefits of the study along with their freedom to withdraw consent at any stage of the study. Privacy was maintained during data collection and confidentiality of data was maintained properly.

Results:

Analysis of 2645 cases attending the camp showed $410(15.5 \%)$ patients having skin diseases while the rest

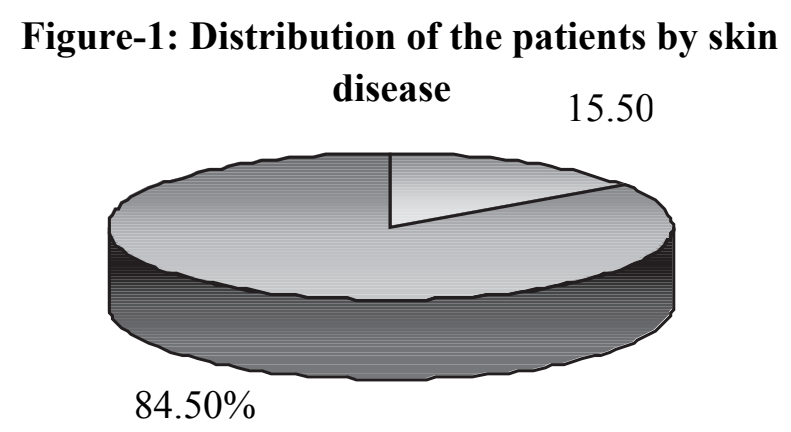

$\square$ Skin disease $\square$ No skin disease

Among the patients, $260(63.4 \%)$ were males and 150 $(36.6 \%)$ were females with a male to female ratio of $1.7: 1$. The general living and hygienic standards of these patients were average to poor and majority of them belonged to lower socioeconomic class with monthly income within Tk.10,000/- of most $(88.7 \%)$ of the patients. A remarkable part $(37.3 \%)$ of the patients was illiterate and majority $(32.25 \%)$ was housewives followed by businessmen (30.4\%), which are shown in the table-1. 
Table-1: Socio-demographic Profile of the Patients $(n=410)$

\begin{tabular}{|l|l|}
\hline \multicolumn{1}{|c|}{ Attribute } & \multicolumn{1}{|c|}{ Finding } \\
\hline Sex & Male: $63.41 \%$, Female: $36.59 \%$ \\
\hline Age (in years) & $\begin{array}{l}15-19: 7.33 \%, 20-30: 44.63 \%, 31-40: 28.41 \%, \\
\text { Mean age ( } \pm \text { SD ) = 32.37 } \pm 7.24 \text { years. }\end{array}$ \\
\hline Education & $\begin{array}{l}\text { Illiterate: } 37.31 \%, \text { Primary: } 30.33 \%, \\
\text { Secondary: } 25.00 \%, \text { SSC: } 4.91 \%, \text { HSC: } 2.45 \% .\end{array}$ \\
\hline Occupation & $\begin{array}{l}\text { House wife: } 32.25 \%, \text { Business: } 30.40 \%, \text { Farmer: } 26.60 \%, \\
\text { Student: } 10.75 \% .\end{array}$ \\
\hline Monthly family income & $\begin{array}{l}\text { Tk.2000 -5000=35.78\%, Tk.500 1-10,000=52.94\%, Tk.10,001 } \\
20,000=10.28 \%, \text { Average ( } \pm \text { SD ) }=\text { Tk. } 6843.14 \pm 2786.77 .\end{array}$ \\
\hline
\end{tabular}

Of these patients, $178(43.4 \%)$ had cutaneous infections and $232(56.6 \%)$ had non-infectious dermatoses (Figure-2). Few patients $(2.7 \%)$ had more than one dermatoses.

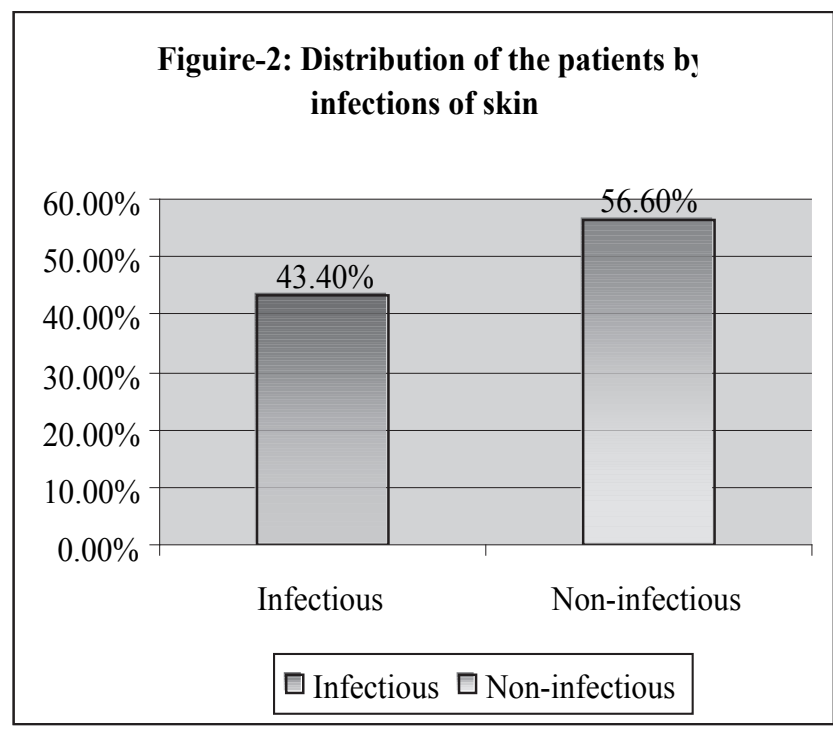

Fungal infection 94 (22.9\%) was the commonest infection seen in the infectious group. Scabies was seen in $42(10.2 \%)$ patients and bacterial infections in $39(9.5 \%)$ patients. Viral infections were seen in $7(1.7 \%)$, pediculosis in $6(1.5 \%)$ patients and leprosy was found only in $2(0.5 \%)$ patients (Table-2).

Table-2: Pattern of cutaneous infection by sex

\begin{tabular}{|l|c|c|c|}
\hline \multicolumn{1}{|c|}{ Infection } & Male & Female & Total \\
\hline Fungal & 62 & 32 & $94(22.9)$ \\
\hline Scabies & 24 & 18 & $42(10.2)$ \\
\hline Bacterial & 30 & 09 & $39(9.5)$ \\
\hline Leprosy & 01 & 01 & $02(0.5)$ \\
\hline Viral & 03 & 04 & $07(1.7)$ \\
\hline Pediculosis & 02 & 04 & $06(1.5)$ \\
\hline
\end{tabular}

Multiple Responses

51
In the non-infectious group, eczema and dermatitis took an upper hand and was observed in 132(32.2\%) patients. Hereditary disorders and psoriasis were seen in $18(4.4 \%)$ patients while pigmentary disorders and autoimmune diseases were found in $12(2.9 \%)$ patients. Acne was seen in $20(4.4 \%)$ patients, deficiency disorders were found in $10(2.4 \%)$ patients and another $20(4.4 \%)$ patients had miscellaneous skin diseases (Table-3).

Table-3: Pattern of non-infectious dermatoses by sex

\begin{tabular}{|l|c|c|c|}
\hline \multicolumn{1}{|c|}{ Infection } & Male & Female & Total \\
\hline Eczema and D ermatitis & 90 & 42 & $132(32.2)$ \\
\hline Hereditary Disorder & 10 & 8 & $18(4.4)$ \\
\hline Pigmentary Disorder & 4 & 8 & $12(2.9)$ \\
\hline Autoimmune Diseases & 8 & 4 & $12(2.9)$ \\
\hline Psoriasis & 10 & 8 & $18(4.4)$ \\
\hline Acne & 8 & 12 & $20(4.8)$ \\
\hline Deficiency Disorder & 4 & 6 & $10(2.4)$ \\
\hline Miscellaneous & 12 & 8 & $20(4.8)$ \\
\hline
\end{tabular}

Multiple Responses

\section{Discussion:}

Analysis of 2645 cases showed 410(15.5\%) patients having skin diseases. Reports from other parts of the neighbor country India also showed similar results like $8.59 \% 1$, $10.50 \% 5$ and $9.98 \% 6$. The prevalence of dermatoses in the tribal population of Dhamrai was found to be $40 \% 7$. Out of all the patients $178(43.4 \%)$ had cutaneous infections and $243(56.6 \%)$ had non-infectious dermatoses. Some other reports showed $53.18 \% 1,46.86 \% 5,38 \% 8$ patients having cutaneous infections and $46.72 \% 1,53.14 \% 5,62 \% 8$ patients with non-infectious dermatoses. Analysis of patients attending the Skin \& STD out-patient department of KMC Hospital, India showed that $44.14 \%$ had cutaneous infections and $56.58 \%$ had noninfectious dermatoses.

Fungal infections dominated the infectious group and eczema took an upper hand in the non-infectious group in all the studies. Fungal infections were seen in $22.9 \%$ of patients. Geographical factors such as season and climate contributed to the higher proportion of fungal infection in this population. High proportion of bacterial infections and scabies can be explained due to the overcrowding, poor resistance, poverty and also poor economic and living standards of these patients.

Leprosy was low in this particular study $(0.5 \%)$ compared to the other studies where it was as high as $11.76 \% 1,5.09 \% 5$ and $4.91 \% 8$ This may be because the population covered in the study were well aware of the disease and seek treatment in the early stage. The proportion of non-infectious dermatoses is similar to the other reports. Finally the study was compared with the incidence of dermatoses from other 
hospital, considering it as representative of an urban population. The only difference was the high incidence of viral infections $(15.73 \%)$ among the hospital patients. This can be explained due to the fact that the hospital has got newer treatment modalities available for treating warts viz. electrocautery and cryotherapy and hence cases are referred from peripheral centers.

\section{Conclusion:}

Improvement in the standard of living, education of the general public, improvement in the environmental sanitation and good nutritious food may help us to bring down the skin diseases in this area.

\section{References:}

1. Dayal SG, Gupta GD. A cross section of skin diseases in Bundelkhand region, UP. Ind J Derm Ven Leprol 1972; 43:258-61.

2. Sample Vital Registration System (SVRS) 2010. Bangladesh Bureau of Statistics (BBS). Dhaka, Bangladesh.
3. National Institute of Population Research and Training (NIPORT), Mitra and Associates, and Macro International. Bangladesh Demographic and Health Survey 2007. Dhaka, Bangladesh and Calverton, Maryland, USA: March 2009

4. Shaikh NA. Pattern of skin diseases in Pakistan. Ind. J Derm Ven Leprol 1962;28:143-5.

5. Gandadharan C, Joseph A, Sarojini PA. Pattern of skin diseases in Kerala. Ind J Derm Ven Leprol 1976; 42:49-51.

6. Jayaram DP. Abstract of presentation in the seminar on pattern of skin diseases in India. Ind J Derm Ven Leprol 1976; 28:147-8.

7. Mahalingam C. Prevalence of dermatoses in tribal population of Kalrayan Hill (South Arcot District). Ind J Derm Ven Leprol 1986;52:213-5.

8. Mehta TK. Pattern of skin diseases in India. Ind J Dem Ven Leprol 1962;28:134-139. 